\title{
Research on the Agglomeration of Jiangsu Electromechanical Industry Based on the Method of Order Relation Analysis
}

\author{
Jingfei $\mathrm{Wu}^{1 *}$ \\ ${ }^{1}$ Department of Economics and Management, Jian Dong College of Vocational and Technology, Changzhou, China
}

\begin{abstract}
Industrial agglomeration is considered by many scholars as a spatial organization that can achieve the highest economic benefits. This article combines the status quo of the export trade of mechanical and electrical products in Jiangsu Province, summarizes its export advantages and difficulties faced by exports, and analyzes the main influencing factors of the formation, development, maturity, and decline of Jiangsu's mechanical and electrical industry clustering from the perspective of the industrial cluster life cycle and the weight of each influencing factor, aiming to inject new vitality into the export of Jiangsu's electromechanical industry, bring better development opportunities, and walk away from emerging development bottlenecks.
\end{abstract}

\section{INTRODUCTION}

\subsection{The export volume of mechanical and electrical products slows down in the post- financial crisis era}

In recent years, Jiangsu's exports of mechanical and electrical products accounted for more than 55\% of Jiangsu's total exports (as shown in Table 1). It has become a new force in promoting the rapid development of Jiangsu's foreign trade with a great contribution rate. The country ranks in the forefront.

From 2000 to 2008, the export value of mechanical and electrical products in Jiangsu Province increased from 9.69 billion US dollars to 136.48 billion US dollars. However, with the increase in comprehensive costs such as labor and exchange rates, the traditional competitive advantages of mechanical and electrical products are gradually weakening. Coupled with the phenomenon of shrinking overseas markets after the global financial crisis in 2008, trade protectionism has risen, and the international industrial division of labor has also experienced profound changes. Changes, Jiangsu's export of mechanical and electrical products gradually slowed down from 2012 to 2015, and even experienced a second negative growth in 2016. As the current economic and trade scale of Jiangsu Province is already very large, it will be difficult for foreign trade to obtain breakthrough development momentum before the new round of technological revolution and the resulting transformation and upgrading generate new growth momentum. Low-speed growth will become the "new normal" of foreign trade.

TABLE 1. EXPORTS OF JIANGSU'S MECHANICAL AND ELECTRICAL PRODUCTS FROM 2008 TO 2018

\begin{tabular}{|l|l|l|l|l|l|}
\hline years & $\begin{array}{c}\text { Mechanical and } \\
\text { electrical exports } \\
\text { (One hundred } \\
\text { million U.S. } \\
\text { dollars) }\end{array}$ & $\begin{array}{c}\text { Year-on- } \\
\text { year } \\
\text { growth }\end{array}$ & $\begin{array}{c}\text { Total exports } \\
\mathbf{1 0 0} \text { million US } \\
\text { dollars) }\end{array}$ & $\begin{array}{c}\text { Year-on- } \\
\text { year } \\
\text { growth }\end{array}$ & $\begin{array}{c}\text { The proportion } \\
\text { of mechanical } \\
\text { and electrical } \\
\text { products in total } \\
\text { exports }\end{array}$ \\
\hline 2008 & 1364.7960 & $14.4 \%$ & 2380.3627 & $16.8 \%$ & $57.3 \%$ \\
\hline 2009 & 1194.4616 & $-12.5 \%$ & 1992.4278 & $-16.3 \%$ & $60.0 \%$ \\
\hline 2010 & 1644.8028 & $37.7 \%$ & 2705.5014 & $35.8 \%$ & $60.8 \%$ \\
\hline 2011 & 1788.0782 & $8.7 \%$ & 3126.2305 & $15.6 \%$ & $57.2 \%$ \\
\hline 2012 & 1807.9423 & $1.1 \%$ & 3244.4163 & $3.8 \%$ & $55.7 \%$ \\
\hline 2013 & 1813.2848 & $0.3 \%$ & 3246.5195 & $0.06 \%$ & $55.9 \%$ \\
\hline 2014 & 1871.7293 & $3.2 \%$ & 3377.4301 & $4.0 \%$ & $55.4 \%$ \\
\hline 2015 & 1889.8514 & $1.0 \%$ & 3336.5671 & $-1.2 \%$ & $56.6 \%$ \\
\hline 2016 & 1739.6215 & $-7.9 \%$ & 3129.1098 & $-6.2 \%$ & $55.6 \%$ \\
\hline 2017 & 1981.1741 & $13.9 \%$ & 3467.1500 & $10.8 \%$ & $57.1 \%$ \\
\hline 2018 & 2216.3355 & $11.9 \%$ & 3844.6034 & $10.9 \%$ & $57.6 \%$ \\
\hline
\end{tabular}

( The data comes from the data compiled by the Jiangsu Provincial Department of Commerce) 


\subsection{The export mode based on processing trade has a tendency to change}

Since it is impossible to obtain the export value of processing trade in Jiangsu's mechanical and electrical product exports, the export value of all processing trade in Jiangsu indirectly reflects the export situation of mechanical and electrical product processing trade. Based on the analysis of the current situation of electromechanical products, it is concluded that although Jiangsu's export mode of electromechanical products based on processing trade has a trend of change, it is more dependent on processing trade. It can be seen that processing trade was the main form of export trade in Jiangsu from 2014 to 2018.

\section{The ADVANTAGES AND DIFFICULTIES OF JIANGSU'S ELECTROMECHANICAL INDUSTRY}

In 2018, there were 3,348 foreign direct investment projects in Jiangsu Province, with a registered agreement of US\$60,522.16 million and actual use of US\$25.59.248 million. Among them, 733 were foreign direct investment projects in mechanical and electrical sectors, accounting for $21.9 \%$.

Foxconn, Taiwan Glass, Darfon and other large-scale leading and base projects have settled in northern Jiangsu, which has strongly promoted industrial transformation and upgrading in northern Jiangsu. The establishment of R\&D centers by foreign capital is accelerating. A large number of world-renowned multinational companies, including Bosch, Ford, Samsung, etc., have invested in Jiangsu and established more than 100 independent legal person foreign R\&D centers, mainly involving biomedicine, electronic information, machinery, automobiles and Parts, new energy, new materials and other fields.

However, most electromechanical enterprises in Jiangsu Province currently lack the ability to independently research and develop new products. The exported electromechanical products rarely have core technologies and independent intellectual property rights, and the proportion of exports of independent brands is less than
$20 \%$. The lack of high-tech talents, low investment in research and development, and lack of awareness of innovation have led to the low technical content of the products exported by electromechanical products, backward processes, and low levels of the industrial chain. The scale of production is expanded to increase benefits. The vast majority of exports of mechanical and electrical products are based on OEM orders. This simple volume expansion model is not conducive to sustainable economic growth and the improvement of international competitiveness.

In addition, with the aging of our country's population, the advantage of the labor force has gradually disappeared. The labor cost in Cambodia, Myanmar, and Bangladesh is far lower than that in our country. The electromechanical industry is a labor-intensive industry, which causes foreign-funded enterprises to choose lower labor costs in Cambodia, Myanmar, India and other countries to invest and set up factories to produce electromechanical products. Even electromechanical enterprises in our province are also facing pressure from the cost of raw materials and labor.

\section{FACTORS INFLUENCING THE CLUSTERING OF JIANGSU'S ELECTROMECHANICAL INDUSTRY}

Based on the main influencing factors of general industry clustering in the whole life cycle, combined with the main problems faced in the process of clustering transformation of Jiangsu electromechanical industry, this paper proposes 11 main influencing factors of Jiangsu electromechanical industry clustering. Specifically include: the degree of specialized division of labor and social collaboration within the industry, open market conditions, diversified export trade methods, flexible cost control strategies, government policy support, a common cultural environment, sufficient social capital, Diversified product export markets, innovative technology support, significant innovation advantages and the creation of independent cluster brands. Table 2 shows the corresponding relationship between the influencing factors and the stages of the industrial cluster life cycle.

TABLE 2. THE MAIN INFLUENCING FACTORS OF JIANGSU'S ELECTROMECHANICAL INDUSTRY CLUSTERING IN THE LIFE CYCLE PROCESS

\begin{tabular}{|l|l|l|l|}
\hline $\begin{array}{c}\text { Industrial cluster life } \\
\text { cycle }\end{array}$ & $\begin{array}{c}\text { Main factors } \\
\text { affecting general } \\
\text { industrial clustering }\end{array}$ & $\begin{array}{c}\text { The main problems of } \\
\text { Jiangsu's electromechanical } \\
\text { industry clustering }\end{array}$ & $\begin{array}{c}\text { The main influencing factors } \\
\text { of Jiangsu's electromechanical } \\
\text { industry cluster }\end{array}$ \\
\hline Formation stage & $\begin{array}{l}\text { Degree of professional } \\
\text { division of labor and } \\
\text { collaboration Open } \\
\text { market conditions }\end{array}$ & - & $\begin{array}{l}\text { Degree of professional division } \\
\text { of labor and collaboration } \\
\text { Open market conditions }\end{array}$ \\
\hline Progression stage & $\begin{array}{l}\text { Common cultural } \\
\text { environment } \\
\text { Government policy } \\
\text { support }\end{array}$ & $\begin{array}{l}\text { The cost of production factors } \\
\text { is higher } \\
\text { Single export trade method }\end{array}$ & $\begin{array}{l}\text { Diversified export trade methods } \\
\text { Flexible cost control strategy } \\
\text { Government policy support } \\
\text { Common cultural environment }\end{array}$ \\
\hline
\end{tabular}




\begin{tabular}{|l|l|l|l|}
\hline Mature stage & $\begin{array}{l}\text { Sufficient social } \\
\text { capital Innovative } \\
\text { technology support }\end{array}$ & $\begin{array}{l}\text { Excessive concentration of } \\
\text { export markets }\end{array}$ & $\begin{array}{l}\text { Sufficient social capital } \\
\text { Diverse product export markets } \\
\text { Innovative technology support }\end{array}$ \\
\hline Recession phase & $\begin{array}{l}\text { Significant innovation } \\
\text { advantage Creation of } \\
\text { independent cluster } \\
\text { brand }\end{array}$ & - & $\begin{array}{l}\text { Significant innovation } \\
\text { advantage } \\
\text { Creation of independent cluster } \\
\text { brand }\end{array}$ \\
\hline
\end{tabular}

\section{Weight Analysis of Factors Affecting JIANGSU'S MECHANICAL AND ELECTRICAL INDUSTRY CLUSTER}

\subsection{Order relation method}

The order relationship analysis method, also known as the G1 method, is proposed for the inconsistency defect of the judgment matrix construction in the analytic hierarchy process. This method is a method of determining the weight of factors without the need for consistency testing. In addition, the order relation method has no limit on the number of schemes, and can fully express the preference of the judgment expert, and its results are highly reliable. Therefore, this paper adopts the method of order relation to determine the weight of the influencing factors of Jiangsu's electromechanical industry clustering.

\subsection{Weight determination}

According to the processing steps of the order relationship method on the factor weight coefficient problem, this paper comprehensively selects 15 experts from 11 companies in the Jiangsu electromechanical industry chain, and collects the importance ranking information of the 11 influencing factors of Jiangsu electromechanical industry clustering through questionnaire surveys. The ratio information of the relative importance of adjacent factors in the sum-order relationship. A total of 40 questionnaires were distributed and 35 valid questionnaires were returned. In order to facilitate the statistics of the survey results, this article simplifies the 11 influencing factors in turn, namely \{ the degree of specialized division of labor and social collaboration within the industry, open market conditions, diversified export trade methods, flexible cost control strategies, government policy support, a common cultural environment, sufficient social capital, diversified product export markets, innovative technology support, significant innovation advantages and the creation of independent cluster brands. $\quad\}=\left\{\mathrm{C}_{1}, \mathrm{C}_{2}, \mathrm{C}_{3}, \mathrm{C}_{4}, \mathrm{C}_{5}, \mathrm{C}_{6}, \mathrm{C}_{7}, \mathrm{C}_{8}, \mathrm{C}_{9}, \mathrm{C}_{10}, \mathrm{C}_{11}\right\}$. The analysis of the survey results of the importance ranking of influencing factors is based on the principle of "the minority obeys the majority", and the number of voters of each influencing factor under each importance ranking number is compared, and the order relationship of the influencing factors of Jiangsu's electromechanical industry clustering is finally determined. According to the ranking results of importance, with reference to the relative importance degree assignment standard, the ratio of the relative importance degree of 15 experts to adjacent influencing factors $r_{k}$ was calculated. After calculating the sum and average, the final value is obtained. The statistics of the two questionnaire surveys are shown in Table 3 and Table 4.

TABLE 3. RANKING RESULTS OF THE IMPORTANCE OF INFLUENCING FACTORS OF JIANGSU'S ELECTROMECHANICAL INDUSTRY CLUSTERING

\begin{tabular}{|c|c|c|c|c|c|c|c|c|c|c|c|}
\hline & $x_{1}^{*}$ & $x_{2}^{*}$ & $x_{3}^{*}$ & $x_{4}^{*}$ & $x_{5}^{*}$ & $x_{6}^{*}$ & $x_{7}^{*}$ & $x_{8}^{*}$ & $x_{9}^{*}$ & $x_{10}^{*}$ & $x_{11}^{*}$ \\
\hline $\mathrm{C}_{1}$ & 6 & 5 & 4 & - & - & - & - & - & - & - & - \\
\hline $\mathrm{C}_{2}$ & 5 & 5 & 3 & 1 & 1 & - & - & - & - & - & - \\
\hline $\mathrm{C}_{3}$ & - & 1 & 2 & 3 & 4 & 1 & - & - & - & 4 & - \\
\hline $\mathrm{C}_{4}$ & - & 2 & 3 & 3 & 3 & 1 & - & - & 3 & - & - \\
\hline $\mathrm{C}_{5}$ & 1 & 1 & 3 & 5 & 5 & & - & - & - & - & - \\
\hline $\mathrm{C}_{6}$ & - & - & 2 & 2 & 2 & - & 3 & - & 2 & 1 & 3 \\
\hline $\mathrm{C}_{7}$ & - & - & - & 1 & 4 & - & 2 & 1 & 1 & 2 & 4 \\
\hline $\mathrm{C}_{8}$ & - & - & - & - & 2 & 5 & 3 & 1 & 2 & 2 & - \\
\hline $\mathrm{C}_{9}$ & - & - & 5 & 3 & 2 & - & - & 2 & 2 & 1 & - \\
\hline $\mathrm{C}_{10}$ & 2 & 2 & 3 & 7 & 1 & - & - & - & - & - & - \\
\hline $\mathrm{C}_{11}$ & 2 & 1 & 6 & 4 & 1 & 1 & - & - & - & - & - \\
\hline $\begin{array}{l}\text { Order } \\
\text { relation }\end{array}$ & \multicolumn{11}{|c|}{$\mathrm{C}_{1} \geq \mathrm{C}_{2} \geq \mathrm{C}_{11} \geq \mathrm{C}_{10} \geq \mathrm{C}_{5} \geq \mathrm{C}_{7} \geq \mathrm{C}_{6} \geq \mathrm{C}_{8} \geq \mathrm{C}_{4} \geq \mathrm{C}_{3} \geq \mathrm{C}_{9}$} \\
\hline
\end{tabular}


The statistics of the order relationship of the influencing factors are carried out in the order of $x_{1}^{*}>x_{2}^{*}>\cdots>x_{m}^{*}$. When the ordering encounters conflicts, first consider whether any of the conflicting factors has already appeared in the ordering relationship, if any, remove the ordered factors, and then the number of votes according to the factors How much is sorted. If none of the conflicting factors appear in the sorting result, refer to the number of voters under other sorting sequence number $x_{m}^{*}$, and the priority sorting with more votes. The statistical analysis and the average results of the relative importance of adjacent influencing factors in the sequence relationship $\mathrm{C} 1 \geq \mathrm{C} 2 \geq \mathrm{C} 11 \geq \mathrm{C} 10 \geq \mathrm{C} 5 \geq \mathrm{C} 7 \geq \mathrm{C} 6 \geq \mathrm{C} 8 \geq \mathrm{C} 4 \geq \mathrm{C} 3 \geq \mathrm{C} 9 \quad$ are shown in Table 4. This questionnaire survey issued 15 questionnaires and 14 valid questionnaires were returned. Therefore, the author only counted 14 Comprehensive value of expert opinions.

TABLE 4. THE RATIO OF RELATIVE IMPORTANCE OF ADJACENT FACTORS IN THE SEQUENCE OF CLUSTERING INFLUENCING FACTORS

\begin{tabular}{|c|c|c|c|c|c|c|c|c|c|c|}
\hline Expert & $r_{2}$ & $r_{3}$ & $r_{4}$ & $r_{5}$ & $r_{6}$ & $r_{7}$ & $r_{8}$ & $r_{9}$ & $r_{10}$ & $r_{11}$ \\
\hline $\mathbf{1}$ & 1.4 & 1.4 & 1.6 & 1.6 & 1.2 & 1.4 & 1.4 & 1.4 & 1.6 & 1.4 \\
\hline $\mathbf{2}$ & 1.2 & 1.6 & 1.4 & 1.4 & 1.4 & 1.2 & 1.3 & 1.6 & 1.4 & 1.2 \\
\hline $\mathbf{3}$ & 1.4 & 1.6 & 1.6 & 1.4 & 1.8 & 1.6 & 1.6 & 1 & 1.7 & 1.6 \\
\hline $\mathbf{4}$ & 1.3 & 1.4 & 1.3 & 1.2 & 1.6 & 1.6 & 1.8 & 1.2 & 1.4 & 1.4 \\
\hline $\mathbf{5}$ & 1.2 & 1.4 & 1.2 & 1.8 & 1.3 & 1.6 & 1.6 & 1.6 & 1.6 & 1.2 \\
\hline $\mathbf{6}$ & 1.4 & 1.6 & 1.4 & 1.4 & 1.8 & 1.4 & 1.7 & 1.2 & 1.6 & 1.4 \\
\hline $\mathbf{7}$ & 1.4 & 1.7 & 1.6 & 1.2 & 1.6 & 1.3 & 1.6 & 1.3 & 1.6 & 1.6 \\
\hline $\mathbf{8}$ & 1.4 & 1.6 & 1.6 & 1.7 & 1.6 & 1.8 & 1.4 & 1.7 & 1.4 & 1.8 \\
\hline $\mathbf{9}$ & 1.2 & 1.6 & 1.7 & 1.6 & 1.2 & 1.4 & 1.4 & 1.6 & 1.3 & 1.3 \\
\hline $\mathbf{1 0}$ & 1.2 & 1.4 & 1.4 & 1.3 & 1.4 & 1.6 & 1.2 & 1.6 & 1.2 & 1.7 \\
\hline $\mathbf{1 1}$ & 1.4 & 1.8 & 1.4 & 1.6 & 1.4 & 1.7 & 1.4 & 1.4 & 1.4 & 1.6 \\
\hline $\mathbf{1 2}$ & 1.3 & 1.4 & 1.6 & 1.8 & 1.8 & 1.6 & 1.2 & 1.4 & 1.8 & 1.4 \\
\hline $\mathbf{1 3}$ & 1.4 & 1.3 & 1.8 & 1.4 & 1.6 & 1.4 & 1.6 & 1.2 & 1.6 & 1.4 \\
\hline $\mathbf{1 4}$ & 1.2 & 1.4 & 1.4 & 1.6 & 1.4 & 1.4 & 1.4 & 1.8 & 1.4 & 1.6 \\
\hline $\begin{array}{c}\text { Compre } \\
\text { hensive } \\
\text { value }\end{array}$ & 1.31 & 1.51 & 1.50 & 1.50 & 1.51 & 1.50 & 1.47 & 1.43 & 1.50 & 1.47 \\
\hline
\end{tabular}

The order relationship can be transformed,

$$
\begin{aligned}
w_{11}^{*}= & \left(1+\frac{w_{10}^{*}}{w_{11}^{*}}+\frac{w_{9}^{*}}{w_{11}^{*}}+\frac{w_{8}^{*}}{w_{11}^{*}}+\frac{w_{7}^{*}}{w_{11}^{*}}+\frac{w_{6}^{*}}{w_{11}^{*}}+\frac{w_{5}^{*}}{w_{11}^{*}}+\frac{w_{4}^{*}}{w_{11}^{*}}+\frac{w_{3}^{*}}{w_{11}^{*}}+\frac{w_{2}^{*}}{w_{11}^{*}}+\frac{w_{1}^{*}}{w_{11}^{*}}\right)^{-1} \\
= & \left(\begin{array}{l}
1+r_{11}+r_{11} r_{10}+r_{11} r_{10} r_{9}+r_{11} r_{10} r_{9} r_{8}+r_{11} r_{10} r_{9} r_{8} r_{7}+r_{11} r_{10} r_{9} r_{8} r_{7} r_{6} \\
+r_{11} r_{10} r_{9} r_{8} r_{7} r_{6} r_{5}+r_{11} r_{10} r_{9} r_{8} r_{7} r_{6} r_{5} r_{4}+r_{11} r_{10} r_{9} r_{8} r_{7} r_{6} r_{5} r_{4} r_{3}+r_{11} r_{10} r_{9} r_{8} r_{7} r_{6} r_{5} r_{4} r_{3} r_{2}
\end{array}\right)^{-1}
\end{aligned}
$$

Substitute the data in Table 4, we can get $w_{11}^{*}=(1+49.8256)^{-1}=0.020 \quad$, After formula

calculation,

$$
\begin{aligned}
& w_{10}^{*}=w_{11}^{*} r_{11}=0.028, w_{9}^{*}=w_{10}^{*} r_{10}=0.035, w_{8}^{*}=w_{9}^{*} r_{9}=0.043 \\
& w_{7}^{*}=w_{8}^{*} r_{8}=0.054, \quad w_{6}^{*}=w_{7}^{*} r_{7}=0.069, \quad w_{5}^{*}=w_{6}^{*} r_{6}=0.089 \\
& w_{4}^{*}=w_{5}^{*} r_{5}=0.135, \quad w_{3}^{*}=w_{4}^{*} r_{4}=0.157, \quad w_{2}^{*}=w_{3}^{*} r_{3}=0.168 \\
& w_{1}^{*}=w_{2}^{*} r_{2}=0.223
\end{aligned}
$$

Table 5 shows the weight coefficients of the influencing factors of Jiangsu's electromechanical industry clustering. 
TABLE 5. INFLUENCING FACTORS AND WEIGHT COEFFICIENTS OF JIANGSU'S ELECTROMECHANICAL INDUSTRY CLUSTER

\begin{tabular}{|l|l|}
\hline \multicolumn{1}{|c|}{ Influencing factors } & \multicolumn{1}{|c|}{$\begin{array}{c}\text { Weight } \\
\text { coefficient }\end{array}$} \\
\hline Degree of professional division of labor and collaboration & 0.223 \\
\hline Significant innovation advantage & 0.168 \\
\hline Creation of independent cluster brand & 0.157 \\
\hline Open market conditions & 0.135 \\
\hline Government policy support & 0.089 \\
\hline Diverse product export markets & 0.069 \\
\hline Innovative technology support & 0.054 \\
\hline Common cultural environment & 0.043 \\
\hline Flexible cost control strategy & 0.035 \\
\hline Diversified export trade methods & 0.028 \\
\hline Sufficient social capital & 0.020 \\
\hline
\end{tabular}

\section{CONCLUSION}

Combined with the main problems in the process of clustering of Jiangsu's electromechanical industry, the main influencing factors of Jiangsu's electromechanical industry clustering during the four stages of formation, development, maturity and decline are analyzed from the perspective of the life cycle of the industrial cluster. Among them, among the 11 main influencing factors of the clustering of Jiangsu's electromechanical industry, the degree of professional division of labor and collaboration, significant innovation advantage, and the establishment of independent cluster brands have the largest weight.

To further promote the agglomeration and development of Jiangsu's electromechanical industry, it is necessary to enhance the competitiveness of the industry from several aspects such as the government's leading role in industrial development, the main role of enterprises in industrial development, and the coordination role of industry associations in industrial development.

\section{REFERENCES}

1. Krugman,RA. Increasing Returns and Economic Geography[C]. NBER Working Paper, 1991(3), No. 3275 .

2. M. Hsu, Y. Lai, F. Lin. Effects of industry clusters on company competitiveness: special economic zones in Taiwan. Review of Pacific Basin Financial Markets \& Policies, 2013, 16(3):1-28.

3. S. C. Chang, S. W. Tein, H. M. Lee. Social capital, creativity and new product advantage: an empirical study. International Journal of Electronic Business Management, 2010, 8(1):43-55.

4. D. Shin, R. Hassink. Cluster life cycles: the case of the shipbuilding industry cluster in South Korea. Regional Studies, 2011, 45(10):1387-1402.
5. P. D. Marthew, F. K. Hugh. Measuring urban agglomeration economies with office rents. Joumal of Eeonomic Geography, 2010: 1-27.

6. J. M. Zhu, X. D. Shi. Research on the impact of industrial cluster social capital on innovation performance-Based on the perspective of industrial cluster life cycle. Studies in Science of Science, 2015, 33(3):449-459.

7. X. F. Fan, X. Q. Kang. Measurement of Shaanxi Manufacturing Industry Agglomeration and Empirical Analysis of Its Influencing Factors[J].Economic Geography, 2013(9):115-119.

8. J. Y. Jiang, S. Y. Zhang. An Empirical Analysis of China's Manufacturing Spatial Agglomeration.China Science and Technology Forum,2007(3):34-38.

9. J. Y. Lu, Z. G. Tao. China's manufacturing industry agglomeration and international comparison. Economic Research. 2006(3):103-114.

10. P. Yu, Y. P. Sun. The influence of agglomeration effect on the location choice of multinational companies in China. Economic Research, 2011, (1): 71-82. 